\title{
Taxes and the Efficiency Costs of Capital Distortions
}

\author{
ALFONS J. WEICHENRIEDER \\ TINA KLAUTKE
}

CESIFO WORKING PAPER NO. 2431

CATEGORY 1: Public FinANCE

OCTOBER 2008

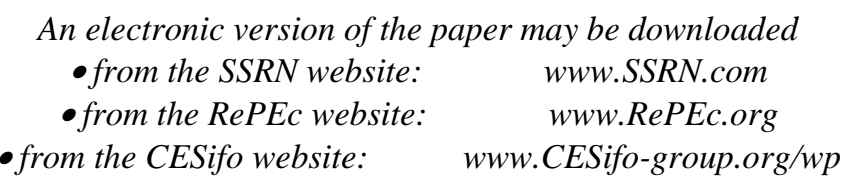




\title{
Taxes and the Efficiency Costs of Capital Distortions
}

\begin{abstract}
Tax neutrality towards alternative financing instruments for corporate investment is a ubiquitous demand in the political debate. At the same time, the literature is surprisingly silent about the magnitude of possible efficiency costs of a departure from tax neutrality. Against this background, the present paper discusses the theory of capital structure and provides backof-the-envelope calculations of the possible efficiency cost of a tax distortion of the debtequity decision.

JEL Code: H25, G32.

Keywords: debt-equity choice, capital structure, excess burden of taxation.

\author{
Alfons J. Weichenrieder \\ Goethe-University Frankfurt \\ Faculty of Economics and Business \\ Administration \\ 60054 Frankfurt (Main) \\ Germany \\ a.weichenrieder@em.uni-frankfurt.de
}

\author{
Tina Klautke \\ Goethe-University Frankfurt \\ Faculty of Economics and Business \\ Administration \\ 60054 Frankfurt (Main) \\ Germany \\ t.klautke@econ.uni-frankfurt.de
}

15 September 2008 


\section{Introduction}

"Financial policy decisions often amount to choosing the optimal trade-off between distortions to financial policy and the tax benefits such distortions generate" (Auerbach 2002, p. 1254). Indeed, in countries with a progressive personal income tax rate on capital income, full financial neutrality may be next to impossible. At the same time, tax neutrality with respect to the debt-equity choice is one of the most frequent demands in discussions about corporate tax reforms.

A part of the economic literature strongly discounts the efficiency cost of tax-induced financial distortions. Proponents of the new view of capital taxation often regard financing flexibility as a buffer that prevents tax discrimination from producing harmful real economic distortions (Sinn 1987, pp. 140 et sqq.). This idea corresponds with the result by Modigliani and Miller (1958) that - in the absence of taxes and costs of bankruptcy and with perfect markets - investors are indifferent to the capital structure.

While the interpretation above considers a corporation's financing flexibility as a buffer for real economic distortions, the finance literature for a long time has contested the idea of financial flexibility. This has led Stewart Myers (1984), in his presidential address to the American Finance Association, to say, "I know of no study clearly demonstrating that a firm's tax status has predictable, material effects on its debt policy. I think the wait for such a study will be protracted." ${ }^{1}$

Uncertainty about the empirical elasticity of the capital structure with regard to fiscal distortions might explain why public-finance scholars have more often scrutinized the consequences of the sensitivity than the possible amount of efficiency loss that results from a

\footnotetext{
${ }^{1}$ Similar doubts about fiscal distortion with regard to corporate financing strategies were raised before by the Nobel laureate Merton Miller (1977, p. 264): "...the debt/asset ratio of the typical nonfinancial corporation in the 1950's was little different from that of the 1920's despite the fact that tax rates had quintupled - from 10 and 11 percent in the 1920's to 52 percent in the 1950's."
} 
fiscal distortion. ${ }^{2}$ In this paper we will make some efforts at presenting estimates of tax distortions as they may be calculated from recent empirical studies.

The remainder of this paper is organized as follows. Section 2 offers a discussion of the standard theories on the capital structure. Section 3 elaborates on the tax advantages of different sources of finance. Section 4 reports on the growing literature that provides empirical estimates of tax effects on debt financing. In Section 5, we use the theoretical model of Section 3 and the empirical results contained in Section 4 to attach numbers to the welfare costs of tax-distorted financing decisions. Section 6 concludes.

\section{Theories of capital structure: a brief outline}

\subsection{The irrelevance hypothesis}

The starting point of the modern theory of corporate finance is Modigliani and Miller (1958). Their insight is as simple as it was surprising at its time: in the absence of taxes and costs of bankruptcy and with perfect capital markets, the value of a corporation will be independent of the debt-asset ratio. The intuition of this result is that the value of a corporation depends on the cash flow produced and what total risk this cash flow implies, and not on how this cash flow is split into dividends versus interest.

Capital structure seems not to be irrelevant in practice. If in a world without taxes the capital structure were irrelevant, then a small tax preference for debt over equity would yield a departure from Modigliani and Miller's irrelevance and would provide for a corner solution of capital structure with full debt financing, which is hardly observed in reality. Certainly, nontax factors of capital structure must come into play.

\footnotetext{
2 The question of the amount of potential efficiency costs remains open in a new voluminous handbook (Auerbach 2002) and an extensive survey by Graham (2003).
} 


\subsection{The trade-off theory}

If indeed the tax system provides a preference for debt, other violations of the assumption by Modigliani and Miller may avoid a corner solution. ${ }^{3}$ A straightforward possibility is that the assumption of zero bankruptcy cost is too heroic. Since a high debt-asset ratio increases the probability of a bankruptcy, a corporation that internalizes part of this cost may forgo some of the benefit of interest deductibility by also using equity to avoid the cost of bankruptcy and also the cost of financial distress.

Asymmetric information on capital markets may add to the problems of excessive debt. Equity holders carry the whole investment costs, but, because of the increased repayment probability for debt, they do not receive the whole expected profits if they extend their investment. This leads to potential efficiency costs, which could be avoided by a reduction of debt. The problems that arise from a conflict of interest between equity and debt holders should be comparatively small if a corporation has sufficient suitable collateral that limits the risk of creditors in case of a default (Scott, 1977), and empirical support for this has been provided for example by Dhaliwal, Trezevant, and Wang (1992).

\subsection{The free-cash-flow hypothesis}

The problem of managerial entrenchment is pervasive in the literature of corporate governance. If managers have better information about the real cost of business and the profit opportunities than shareholders, then managers may fail to maximize shareholder value but follow their own goals. Shareholder monitoring to curb managers may be inefficiently low if highly diversified ownership leads to free riding by owners. In such a situation, debt may have a nontax advantage over equity (Jensen, 1986). This advantage results because debt is a disciplining device for management. Projects or corporations that are debt-financed must at least yield a return that covers the fixed interest to stay solvent. The need to serve the interest 
on debt reduces the free cash flow and reduces the discretion of managers to pursue projects that foster their own interest (e.g., empire building) but not those of the shareholders.

One potential problem with the disciplinary role of a high debt-equity ratio is its implementation: in the absence of shareholders' monitoring, the disciplinary effect of debt may indeed be an argument for managers to avoid debt and prefer retention policies (Myers, 2001). Conversely, Zwiebel (1996) and Grossman and Hart (1982) emphasize the role of potential takeovers as a mechanism that may urge managers to issue debt even in the absence of powerful shareholders.

\subsection{The pecking-order hypothesis}

While the free-cash-flow hypothesis addresses a moral hazard problem, the peckingorder theory by Myers and Majluf (1984) is based on an adverse-selection model. It assumes a corporation that acts in the best interest of existing shareholders and therefore will find it optimal (from the point of view of existing shareholders) to issue shares if the market valuation is too high in the light of private management information. Hence, in the case of information asymmetries, the share market will tend to interpret new share issues as a signal of overvaluation, and new share issues will lead to a price decrease, which is to be avoided in the interest of existing shareholders.

Given that valuation problems of debt are less severe than those of equity, the share price decrease following an issue is less pronounced for debt than for equity. Therefore the pecking-order theory predicts that firms will use internal financing sources first and revert to external debt and, even more reluctantly, to new equity only after internal sources of finance have been exhausted.

\footnotetext{
${ }^{3}$ It should be noted that the sole consideration of corporate tax and tax deductibility of interest is not sufficient for a tax preference for debt financing. See Section 3.
} 
While there are several empirical studies that find some evidence in favor of the pecking-order hypothesis, ${ }^{4}$ we will in the following abstract from it. The main reason is that it rather is a theory of financing tactics than a theory of the overall debt-equity choice, but the latter is required to arrive at welfare implications of a distorted debt-equity ratio.

\section{Trade-off theory and taxes: a basic synthesis}

This section extends the theory of tax preferences, as developed by King (1977), King and Fullerton (1984), and Sinn (1987), by imposing a well-defined optimal debt-asset ratio in the absence of tax considerations. This optimal debt-asset ratio may arise from a combination of the theoretical arguments above. According to the trade-off theory bankruptcy costs are an argument for a low debt ratio. The free-cash-flow hypothesis finds it optimal (from the point of view of existing shareholders) to have a high debt ratio to reduce the free cash flow and the discretion of managers to pursue non-profit-maximizing behavior.

To describe the tax system, let $t_{p}$ denote the shareholders' tax rate on personal interest income, $t_{d}$ their tax rate on dividend payments, and $c$ their effective capital gains tax rate. $\Theta$ characterizes the type of the corporate tax system: $\Theta=1$ represents a classical system without imputation of corporate tax on the personal level, and $\Theta>1$ if an imputation credit is available. More precisely, $\Theta$ captures the amount of the dividend payment before personal income tax, if a corporation wants to distribute a profit of one euro after corporate taxation.

Now, consider an investor who has to decide between holding and selling her shares. ${ }^{6}$ She is indifferent if the net-of-tax dividends and the capital gains compensate her for the opportunity costs, which arise because she could sell the shares at the going market value. Omitting time subscripts, we obtain

\footnotetext{
${ }^{4}$ See Dierkens (1991), D’Mello and Ferris (2000), Eckbo (1996), or Shyam-Sunder (1991).

${ }^{5}$ Since usually tax systems tax realized rather than accrued capital gains, the longer the holding period, the larger the difference between effective and nominal rates. Typical effective tax rates on capital gains may be in the range of half the nominal rates (cf. King, 1977, chapter 3).
} 


$$
\begin{aligned}
& D \Theta\left(1-t_{d}\right)+(\dot{V}-Q)(1-c)=i\left(1-t_{p}\right) V \\
& \Leftrightarrow \dot{V}=\frac{i\left(1-t_{p}\right)}{1-c}-D \frac{\Theta\left(1-t_{d}\right)}{1-c}+Q .
\end{aligned}
$$

$V$ captures the going market value, $\dot{V}$ represents its change over time, $i$ is the interest rate on investment in the capital markets, and $D$ represents corporate dividend payments that are paid from after-tax profits. Following the new view of capital income taxation, we assume a mature, dividend-paying corporation. Let $Q$ be the new investment of a shareholder in the company. Integrating $\dot{\boldsymbol{V}}$ forward over time, setting the integration constant to zero, and assuming a constant market rate of interest yields the current market value as follows: ${ }^{7}$

$$
V_{0}=\int_{0}^{\infty}\left(D \frac{\Theta\left(1-t_{d}\right)}{1-c}-Q\right) \exp \left[-\frac{i\left(1-t_{p}\right) s}{1-c}\right] d s
$$

Since we are interested in the cost of financial distortions rather than in the distortion of overall investment, there is no loss in assuming that capital does not depreciate, net investment is zero, and the capital stock is constant and standardized to unity. Thus dividends paid out by the corporation may be financed by the current earnings net of interest and tax, by a change in debt, or by new issues:

$$
D=\left(1-t_{u}\right)[f(K)-i B-\Psi]+\dot{B}+Q
$$

In equation (3), the corporate tax rate is denoted by $t u$, the function $\Psi$ captures the nontax costs of a tax-distorted capital structure, and $f(K)$ is the cash flow of real capital $K$. Since the capital stock is unity, $B$ captures not only the amount of debt but also the debt-asset ratio. The costs of capital-structure distortions arise when the actual real debt-asset ratio $B$ departs from the optimal ratio $B^{*}$ :

\footnotetext{
${ }^{6}$ See Sinn (1987, chapter 3).
} 


$$
\begin{array}{r}
\Psi=\Psi\left(B-B^{*}\right), \Psi(0)=0, \Psi^{\prime}<0, \Psi^{\prime \prime}>0 \text { for } B<B * \\
\Psi^{\prime}>0, \Psi^{\prime \prime}>0 \text { for } B>B *
\end{array}
$$

In the following, it is assumed that the convex costs of the distorted debt-asset ratio provide an inner solution for the debt ratio.

Given a fixed amount of total assets, the only flow of motion is given by changes in debt:

$$
\dot{B}=b
$$

Ignoring the nonnegativity constraints, the current value Hamiltonian is given by

$$
H=-Q+\frac{\Theta\left(1-t_{d}\right)}{1-c}\left\{\left(1-t_{u}\right)\left[\pi-i B-\Psi\left(B-B^{*}\right)\right]+b+Q\right\}+\lambda_{B} b,
$$

where $\pi=f(1)$. From the shareholder's point of view, $\lambda_{B}$ captures the (negative) shadow value of a marginal unit of debt that a corporation owes to its creditors. On the basis of the Hamiltonian, the influence of restructuring corporate finance on the corporate value can be shown. An increase in new issues and a simultaneous increase in dividend payments that does not touch the basis of financing are given by

$$
\partial H / \partial Q=\frac{\Theta\left(1-t_{d}\right)}{1-c}-1
$$

Since realistically $c<t_{d}$, dividend payments and the repatriation through new issues are only attractive if an imputation system provides a $\Theta$ that is sufficiently high. If a full imputation system is implemented with $\Theta=1 /\left(1-t_{u}\right), \mathrm{c}>0$ and $t_{u}=t_{d}$ distribution of company profits combined with an issue of new shares will be tax efficient.

As derived in equation (7), one should notice that, depending on the sign of $\Theta\left(1-t_{d}\right)$ $\left(1-t_{u}\right)-(1-c)\left(1-t_{u}\right)$, one of the two kinds of equity strictly dominates the other, thus leading to corner solutions in the choice of equity type (even as an interior debt-asset ratio prevails). If the tax burden on distributed profits, as measured by $1-\Theta\left(1-t_{d}\right)\left(1-t_{u}\right)$, is

\footnotetext{
${ }^{7}$ To simplify matters, the market rate of interest $i$ is assumed to be constant. The integration constant is set to | zero.
} 
higher than the tax burden on retained profits, as measured by $1-(1-c)\left(1-t_{u}\right)$, then $\partial H / \partial Q$ $<0$ applies and new issues of shares will decrease the value of the corporation. In the reversed situation it is optimal to distribute all the profits as dividends and to compensate by issuing new equity. We will treat these cases in turn.

\section{Case A: Equity vs. debt if retentions dominate new issues}

First, consider the influence of taxes on the leverage in case equity is obtained through retentions. The advantage of a marginal increase in debt can be derived from the Hamiltonian:

(8) $\quad \partial H / \partial b=\frac{\Theta\left(1-t_{d}\right)}{1-c}+\lambda_{B}$.

If the convex costs of a deviation from the optimal debt level $B^{*}$ lead to an inner solution of the optimal debt level, we obtain

(9) $\partial H / \partial b=0 \Rightarrow \lambda_{B}=-\frac{\Theta\left(1-t_{d}\right)}{1-c}$.

Another optimality constraint is given by the canonical equation of the Hamiltonian (6):

(10) $\partial H / \partial B+\dot{\lambda}_{B}=\lambda_{B} i \frac{1-t_{p}}{1-c}$

which can be rewritten using equations (6), (9) and the steady-state condition $\dot{\lambda}_{B}=0$ :

$$
\Psi^{\prime}\left(B-B^{*}\right)=i\left(\frac{\left(1-t_{p}\right)}{(1-c)\left(1-t_{u}\right)}-1\right) \text {. }
$$

The sign on the left-hand side indicates the direction of the deviation from the debt level $B^{*}$, which would be optimal in the absence of taxes. In consideration of (4) we get

$$
B\left\{\begin{array}{l}
> \\
<
\end{array}\right\} B * \text { for }\left(1-t_{p}\right)\left\{\begin{array}{l}
> \\
<
\end{array}\right\}(1-c)\left(1-t_{u}\right) .
$$

Whether taxation favors retained profits or debt depends on whether the effective tax rate on household savings is higher or lower than the effective tax rate on corporate returns. If 
a corporation distributes its profits and the shareholder saves these funds privately, she will receive $i\left(1-t_{p}\right)$ as an interest payment after personal tax. If a corporation saves, then the cumulated tax burden is received from the shareholders' capital gains taxes and the corporate tax, and the net-of-tax return equals $i\left(1-t_{u}\right)(1-c)$. The tax burden on dividend payment, which is captured by the variables $\Theta$ and $t_{\mathrm{d}}$, turns out to be irrelevant in the arbitrage calculation, because, with constant tax rates, it is independent of whether a dividend is paid today or tomorrow and cannot be avoided. ${ }^{8}$ Ceteris paribus, a higher corporate tax rate will tend to shift the financial preference towards debt.

\section{Case B: Equity vs. debt if new issues dominate retained earnings}

Although empirically, retained earnings seem to be quantitatively more important than new issues for mature firms, it is conceivable to have a tax system in which new shares are taxfavored over retentions (see equation (7)). In this case, a marginal financial redeployment from equity to debt leads to a zero effect on the company value in an inner financing solution:

$$
\partial H / \partial b-\partial H / \partial Q=\lambda_{B}+1=0 \Rightarrow \lambda_{B}=-1 .
$$

Given the canonical equation (10) and the steady-state condition $\dot{\lambda}_{B}=0$, we obtain

$$
\Psi^{\prime}\left(B-B^{*}\right)=i\left(\frac{\left(1-t_{p}\right)}{\Theta\left(1-t_{d}\right)\left(1-t_{u}\right)}-1\right) .
$$

Hence, from the assumption (4) the following condition holds:

$$
B\left\{\begin{array}{l}
> \\
<
\end{array}\right\} B^{*} \text { for }\left(1-t_{p}\right)\left\{\begin{array}{l}
> \\
<
\end{array}\right\} \Theta\left(1-t_{d}\right)\left(1-t_{u}\right) .
$$

Again, the effective tax rate on private savings and corporate tax returns is decisive. The former is simply given by $t_{\mathrm{p}}$, while the latter equals $1-\Theta\left(1-t_{d}\right)\left(1-t_{u}\right)$. Unlike in the case of comparing retentions with debt, the taxation of dividends, as captured by $\Theta\left(1-t_{d}\right)$, is

\footnotetext{
${ }^{8}$ See King (1977), King and Fullerton (1984), Sinn (1987).
} 
relevant for the financial preferences, as the tax burden on distributed profits can now be omitted by reducing new equity and increasing the use of debt. As in case A, a higher corporate tax rate on retentions, $t_{u}$, tends to shift the financial preference towards debt.

\section{Taxes and the debt-equity ratio: empirical results}

\subsection{Exploiting differences in nondebt tax shields}

As shown in Section 3, an increased corporate tax rate should increase the advantage of debt and lead to larger leverage. A fundamental problem in empirically identifying this effect is that often all corporations in an economy are subject to the same corporate tax rate $t_{\mathrm{u}}$. Usually, the nominal corporate tax rate is the same for all corporations in the same country, and the variation over time is often very small. ${ }^{9}$

A possible way out was suggested by DeAngelo and Masulis (1980). They argued that tax advantage of debt should be highest for firms that, because of other deductions like loss carryforwards or investment tax credits, may have difficulties in using all debt shields. Thus, one should expect a substitution effect between investment-related tax relief and the use of debt. This hypothesis has been empirically confirmed by MacKie-Mason (1990). In contrast to earlier empirical work on the DeAngelo-Masulis hypothesis that largely failed to identify tax effects, ${ }^{10}$ MacKie-Mason does not use the debt-asset ratio as the endogenous variable, but explains the propensity of U.S. firms to issue bonds or new equity on the basis of a probit analysis. While this approach, together with other modifications, led to significant effects that

\footnotetext{
${ }^{9}$ Along with corporate taxes, personal taxes are often changed as well, so that the variation of the corporate tax rate only leads to limited effects on the financing incentives.

${ }^{10}$ See, e.g., Ang and Peterson (1986), Bradley, Jarrell, and Kim (1984), Fischer, Heinkel, and Zechner (1989), Long and Malitz (1985), Marsh (1982), and Titman and Wessels (1988).
} 
are in line with theoretical expectations, the empirical results fail to provide evidence on the effect of taxation on the optimum debt-equity ratio. ${ }^{11}$

\subsection{Studies with cross-section variation in national nominal tax rates}

A natural approach to identify tax effects is to use the debt-asset ratio as an endogenous variable and explain it by variations in the nominal corporate tax rate. To overcome the obvious problem that in a given year all corporations may be subject to the same tax rate, Gordon and Lee (2001) exploit the fact that small firms in the U.S. enjoy a lower corporate tax rate. They find a significant influence of the instrumented tax rate on financial policy, using a difference-in-difference approach. The results show that large firms generally have a lower debt ratio than small firms. At the same time, this debt difference is smaller in years in which large firms are subject to a higher corporate tax rate. They conclude that a 10-percentage-point increase in the corporate tax rate may increase the debt-asset ratio by some 3.5 percentage points.

A further study by Graham (1999) also tries to explain the debt-asset ratio, but uses market values for debt and equity (instead of book values). The influence of the corporate tax on the debt-asset ratio is identified by using tax rate variations across U.S. states as well as firm-specific loss carryforwards and other firm characteristics. The pooled cross-section analysis from 1980 to 1994 (65,429 firm-years) yields the expected positive effects of the tax rate on the debt-asset ratio. The estimates imply that an increase of 10 percentage points in the national corporate tax rate causes an increase of 1 to 2 percentage points of corporate debt. Besides the statutory tax rate, Graham also uses federal tax rates. In a pooled estimation, a marginal coefficient of 0.24 results, while a fixed-effects estimation produces a coefficient of

\footnotetext{
11 In a similar vein, Alworth and Arachi (2001, p. 375) conclude, when interpreting their own results from MacKie-Mason-type regressions, "...since the estimates relate to changes in company indebtedness [...] the results do not provide a guidance to the impact of taxes on the debt/equity ratio. If one is to assess alternative tax policies on both company decisions and tax revenues it is important to be able to arrive at a quantitative estimate on stock variables."
} 
0.46. According to this latter figure, an increase of 10 percentage points in the tax rate would cause a relatively large increase in the debt-asset ratio, by 4.6 percentage points. ${ }^{12}$

\subsection{Studies with variations in international tax rates}

The limited cross-section variation in corporate taxes has also been overcome by building on samples of subsidiaries operating in different host countries. Altshuler and Grubert (2003) estimate the host country's corporate tax rate for some 6,000 U.S. subsidiaries abroad. The statistics of income from the IRS, which include industries in all sectors (including the financial sector), are used as the database. Affiliates in high-tax countries are significantly more financed with debt than affiliates in low-tax countries. The estimated coefficients suggest that an increase of 10 percentage points in the corporate tax rate in the host country, depending on the empirical model, increases the debt/asset ratio by an amount in the range of 1.3 to 3.9 percentage points. Desai, Foley, and Hines (2004) also look into corporate financing of U.S. affiliates abroad. They use inquiries of the Bureau of Economic Analysis that enable the authors to run panel regressions (fixed effects). According to their results, a 10-percentage-point increase of the corporate tax rate leads to a 2.5-percentage-point increase of the debt ratio. One-fourth of this effect arises from the increase of intrafirm debt, and three-fourths comes from the increase of debt from third parties (outside debt holders). Similar magnitudes of the tax effects on borrowing have been found by Huizinga, Laeven, and Nicodème (2008).

The capital structure of German affiliates abroad is analyzed by Mintz and Weichenrieder (2005) using panel data and fixed-effects models. For a sample of corporations that are wholly owned by their respective German parents, a linear regression of the host country's tax rate on the debt ratio of German affiliates yields a marginal effect of 0.44: a 10percentage-point increase in the foreign tax rate causes an increase in the debt ratio of 4.4

\footnotetext{
12 The paper provides no information on whether the $F$-statistic is significant for the firm fixed effects.
} 
percentage points. Allowing for a nonlinear relation, the marginal effect increases to 0.57 . Including partly owned subsidiaries in the sample reduces the coefficients. In this case, the estimated marginal effect of the linear specification is 0.3 , and that of the nonlinear specification 0.41 . In contrast to U.S. studies, a large fraction of the financing flexibility of German affiliates results from the change of intrafirm credits. ${ }^{13}$

\section{Calculating the efficiency costs of the distorted capital structure}

While for quite some time tax effects on corporate financing decisions have been disputed, from today's point of view, empirical studies reveal a measurable, albeit moderate, effect on the capital structure. Studies that measure a linear effect on the debt ratio suggest that an increase of 10 percentage points in the corporate tax rate increases the debt-asset ratio by 1.4 to 4.6 percentage points. So what efficiency costs can be expected on the basis of these estimates? So far, the literature has been silent on this, and we should emphasize that quite heroic assumptions are needed to arrive at the specific values provided below.

- We assume that all costs of a distorted financing structure accrue to the corporation, meaning that these costs cannot be shifted to creditors or third parties.

- Corporations are identical, so that it is adequate to look at one representative corporation.

- The representative corporation maximizes its value according to the fiscal and nonfiscal costs, as described in Section 3.

- Corporate investment decisions are assumed to be fixed, and only the question of the financing of the capital stock is yet to be decided on. It is only this distortion that is singled out. 
- The costs of a distorted capital structure are supposed to be quadratic and increasing in the deviation of the optimal debt-asset ratio $B^{*}$ in the absence of taxes from the actual ratio $B^{\circ}$ with taxation. The costs only depend on the absolute value of the deviation, not on its sign.

- All costs of a distorted capital structure that are realized by the corporation are real costs. That is, there are no corresponding rents accruing to outsiders, which might compensate for the cost to the corporation.

Given these assumptions, we can take equation (11) as a starting point to derive the size of the marginal (nontax) cost $\Psi^{\prime}$ if a corporation deviates from the optimal debt ratio because of tax considerations. ${ }^{14}$ Figure 1 illustrates the information that is necessary to evaluate the efficiency costs if debt is tax-preferred. In the top part of the diagram the quadratic cost function $\Psi\left(B^{\circ}-B^{*}\right)$ is depicted, leading to a linear marginal-cost curve in the bottom part. Since the capital stock is normalized to one, the actual debt level $B^{\circ}$ also identifies the debt ratio. According to equation (11) these marginal costs equal $i\left(\left(1-t_{\mathrm{p}}\right) /[(1-\right.$ $\left.\left.c)\left(1-t_{\mathrm{u}}\right)\right]-1\right)$ in an inner financial equilibrium. The efficiency costs $(\Psi)$ are given by the triangle $B^{*} c B^{\circ}$ and can be calculated as

$$
\Psi\left(B^{\circ}-B^{*}\right)=\frac{1}{2} i\left(\frac{1-t_{p}}{(1-c)\left(1-t_{u}\right)}-1\right) \cdot\left|B^{*}-B^{\circ}\right| .
$$

\footnotetext{
${ }^{13}$ Ramb and Weichenrieder (2005) failed to find evidence for the influence of the home country of the parent firm on the debt ratio of German subsidiaries. Very small home-country effects have been identified by Huizinga, Leaven, and Nicodème (2008).

${ }^{14}$ Here, we concentrate on the constellation of case A in Section 3. Empirically, it is much more common that retained earnings are tax-preferred over new issues than vice versa.
} 
Figure 1: Efficiency costs of capital distortion

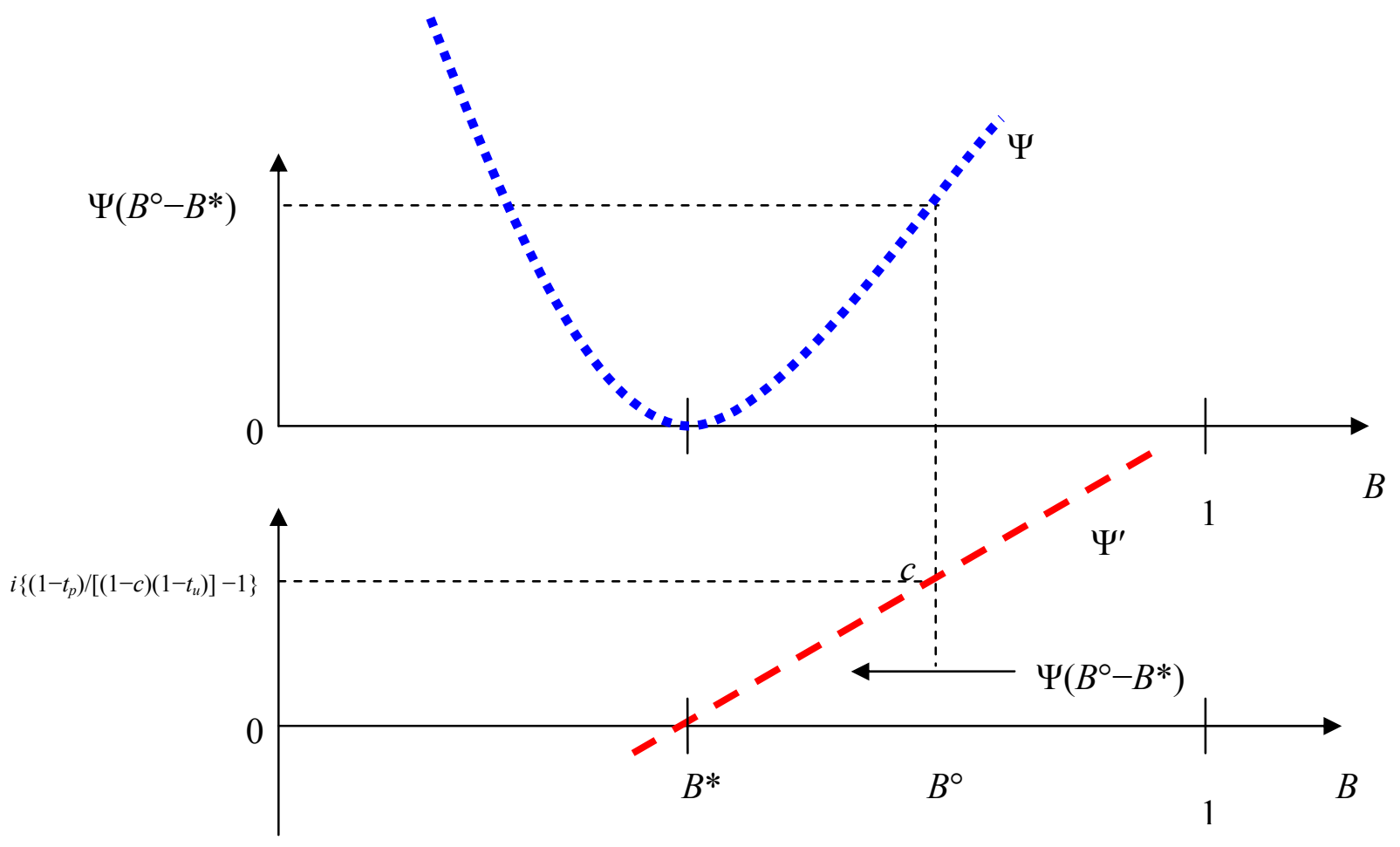

To arrive at the cost $\Psi$, we obviously need the difference $B^{*}-B^{\circ}$ that is triggered by taxation. If we define

(17) $\gamma \equiv d B / d t_{u}$

then the empirical estimations presented in Section 4 suggest $0.14 \leq \gamma \leq 0.46$. This allows for a calculation of the costs $\Psi$ using the formula:

(18) $\Psi\left(B^{\circ}-B^{*}\right)=\frac{1}{2} i \gamma \Delta t_{u}\left(\frac{1-t_{p}}{(1-c)\left(1-t_{u}\right)}-1\right)$. 
It should be noted that a change in the corporate tax rate according to equation (11) has a marginal effect on the debt ratio $B^{\circ}$ that depends on the level of the personal income taxes. However, only unconditional estimations of $\gamma$ are available, which do not consider the levels of $t_{p}$ or $c$. In a similar vein, the assumption of a linear relation between $B^{\circ}$ and $t_{\mathrm{u}}$ is not necessarily plausible and is due to the limitations of the empirical results. Indeed, the quadratic cost function $\Psi=(1 / 2) \cdot a \cdot\left(B^{\circ}-B^{*}\right)^{2}, a>0$, yields a convex relation between $B^{\circ}$ and $t_{u}$.

Allowing for these simplifications, Table 1a illustrates for several values of $\gamma$ how a negative value of $\Delta t_{u}$ would influence the cost $\Psi$ when we start from financial neutrality with $t_{p}=t_{u}, c=0$, and go to $t_{u}=t_{p}+\Delta t_{u}$, keeping tax rates other than the corporate rate constant. This corresponds with the situation in many important industrial countries where the corporate tax rate falls short of the top personal income tax rate (Fuest, Huber, and Nielsen, 2002). More precisely, the table presents the current efficiency cost as a fraction of the nominal interest rate. If we think in terms of an infinite-lived investment and use the interest rate for discounting, this also reflects the total present value of the excess burden associated with one unit of investment.

Table 1a: Illustrative values for $\Psi / i ; \Delta t_{u}<0$

\begin{tabular}{|c|c|c|c|c|c|}
\hline \multicolumn{6}{|c|}{ Starting point $t_{p}, t_{u}=40 \%$} \\
\hline$\gamma$ & 0.3 & 0.3 & 0.3 & 0.3 & 0.3 \\
\hline$\Delta t_{u}$ & -0.02 & -0.05 & -0.1 & -0.2 & -0.3 \\
\hline$\Psi / i$ & 0.005 & 0.012 & 0.021 & 0.038 & 0.050 \\
\hline \multicolumn{6}{|c|}{ Starting point $t_{p}, t_{u}=30 \%$} \\
\hline$\gamma$ & 0.3 & 0.3 & 0.3 & 0.3 & 0.3 \\
\hline$\Delta t_{u}$ & -0.02 & -0.05 & -0.1 & -0.2 & -0.3 \\
\hline$\Psi / i$ & 0.004 & 0.010 & 0.019 & 0.033 & 0.045 \\
\hline \multicolumn{6}{|c|}{ Starting point $t_{p}, t_{u}=30 \%$} \\
\hline$\gamma$ & 0.2 & 0.2 & 0.2 & 0.2 & 0.2 \\
\hline$\Delta t_{u}$ & -0.02 & -0.05 & -0.1 & -0.2 & -0.3 \\
\hline$\Psi / i$ & 0.003 & 0.007 & 0.013 & 0.022 & 0.030 \\
\hline \multicolumn{6}{|c|}{ Starting point $t_{p}, t_{u}=30 \%$} \\
\hline$\gamma$ & 0.4 & 0.4 & 0.4 & 0.4 & 0.4 \\
\hline$\Delta t_{u}$ & -0.02 & -0.05 & -0.1 & -0.2 & -0.3 \\
\hline$\Psi / i$ & 0.006 & 0.013 & 0.025 & 0.044 & 0.060 \\
\hline
\end{tabular}


It is striking that the deadweight loss in Table $1 \mathrm{a}$ is not a quadratic function of $\Delta t_{u}$. This is due to the fact that $\Delta t_{u}$ does not equal the height of the Harberger triangle $B^{*} c B^{\circ}$. This is rather given by $i\left(\left(1-t_{p}\right) /\left[(1-c)\left(1-t_{u}\right)\right]-1\right)$. Because of the bracket term, the calculated size of the Harberger triangle is a convex function of $t_{u}$. For $\Delta t_{u}<0$ this leads to a depressant effect on the size of the deadweight loss. The reverse effect results in the case $\Delta t_{u}>0$. This case is consistent with the standard assumption in the U.S. literature that the tax system favors leverage, and it is presented in Table $1 \mathrm{~b}$. While the calculated efficiency losses are comparable to those of Table 1a for moderate distortions and $\left|\Delta t_{u}\right| \leq 0.1$, much larger magnitudes are calculated if $\left|\Delta t_{u}\right|$ is large.

Taking the intermediate assumption that $\left|\Delta t_{u}\right|=0.1$ and picking an interest rate of $5 \%$, then our calculations indicate that in current values the excess burden amounts to some 5 to 15 basis points or $0.05 \%$ to $0.15 \%$ of the invested capital.

Table 1b: Illustrative values for $\Psi / i ; \Delta t_{u}>0$

\begin{tabular}{|c|c|c|c|c|c|}
\hline \multicolumn{6}{|c|}{ Starting point $t_{p}, t_{u}=40 \%$} \\
\hline$\gamma$ & 0.3 & 0.3 & 0.3 & 0.3 & 0.3 \\
\hline$\Delta t_{u}$ & 0.02 & 0.05 & 0.1 & 0.2 & 0.3 \\
\hline$\Psi / i$ & 0.005 & 0.014 & 0.030 & 0.075 & 0.150 \\
\hline \multicolumn{6}{|c|}{ Starting point $t_{p}, t_{u}=30 \%$} \\
\hline$\gamma$ & 0.3 & 0.3 & 0.3 & 0.3 & 0.3 \\
\hline$\Delta t_{u}$ & 0.02 & 0.05 & 0.1 & 0.2 & 0.3 \\
\hline$\Psi / i$ & 0.004 & 0.012 & 0.025 & 0.060 & 0.113 \\
\hline \multicolumn{6}{|c|}{ Starting point $t_{p}, t_{u}=30 \%$} \\
\hline$\gamma$ & 0.2 & 0.2 & 0.2 & 0.2 & 0.2 \\
\hline$\Delta t_{u}$ & 0.02 & 0.05 & 0.1 & 0.2 & 0.3 \\
\hline$\Psi / i$ & 0.003 & 0.008 & 0.017 & 0.040 & 0.075 \\
\hline \multicolumn{6}{|c|}{ Starting point $t_{p}, t_{u}=30 \%$} \\
\hline$\gamma$ & 0.4 & 0.4 & 0.4 & 0.4 & 0.4 \\
\hline$\Delta t_{u}$ & 0.02 & 0.05 & 0.1 & 0.2 & 0.3 \\
\hline$\Psi / i$ & 0.006 & 0.015 & 0.033 & 0.080 & 0.150 \\
\hline
\end{tabular}

To reiterate, the above calculations imply some stark simplifications, and it is worthwhile to discuss possible modifications. One possibility is that a distorted financial structure induces external costs that are not borne by the corporation. For example, higher 
corporate debt ratios may induce a higher macroeconomic volatility, the cost of which is not priced in a corporation's individual financial cost. This may lead to a situation in which the overall cost of a tax preference for debt is higher than indicated by the value of $\Psi$.

On the other hand, externalities may lead to distortions in the financial structure even in the absence of taxation. In this case tax distortions may even improve welfare. Fuest, Huber, and Nielsen (2002) argue that if the market treats issuance of new equity as a signal for low profitability, then it may be desirable to reduce the managers' preference for debt by making debt tax-disadvantaged.

Another issue that has been abstracted from is firm heterogeneity. If corporations have different flexibilities in reacting to tax incentives with their financial structure, then applying the average marginal effects to all firms may underestimate the total welfare loss. This firm heterogeneity may also imply that different firms may have different cost of capital. For example, a tax preference for debt may be most valuable for companies that are able to use a large amount of debt. This in turn has implications for the investment incentives that have been kept out of the picture above.

\section{Conclusions and Outlook}

The search for the determinants of corporate capital structure is central to finance research, and scholarly articles abound. The present paper has analyzed capital structure choice from a public finance perspective. In particular, it has attempted to evaluate the efficiency costs of a distorted financial structure. Knowledge about these costs is economically relevant, because the aim of financial neutrality may conflict with other political objectives, like implementing a progressive tax system. International tax competition with its moderating effect on corporate tax rates may also raise the question of the costs of differentiating personal and corporate taxes. 
The calculations that have been suggested in this paper imply that a difference between the corporate tax and the personal income tax equal to 10 percentage points may lead to yearly efficiency costs per unit of total assets that lie between 1.3 and 3.3 percent of the nominal interest rate.

While this is a first attempt to attach numbers to the cost of financial distortions, it should be emphasized that strong assumptions had to be employed to do so. Among other things, we abstracted from external costs of a distorted capital structure and assumed that all costs are internalized by corporations and the total amount of investment is kept constant. We made use of empirical estimates of the marginal effects of the corporate tax rate on the debtasset ratio by assuming that this marginal effect is constant, although a constant marginal effect is not necessarily plausible. Even if one ignores these problems, as done in this article, there are only a limited number of empirical studies that analyze the correlation between the corporate tax rate and the debt ratio, and the spread in results is considerable. Finally, many studies depend on a comparison of international corporations that operate among different national corporate taxes. Whether the parameter values that have been derived from these studies are representative for national corporations deserves further investigation. 


\section{References}

Altshuler, R. and H. Grubert (2003), "Repatriation taxes, repatriation strategies and multinational financial policy," Journal of Public Economics 87, 73-107.

Alworth, J. and G. Arachi (2001), "The effect of taxes on corporate financing decisions: Evidence from a panel of Italian firms," International Tax and Public Finance 8, 353-376.

Ang, J.S. and D.R. Peterson (1986), "Optimal debt versus debt capacity: A disequilibrium model of corporate debt behavior," in: A.H. Chen (ed.), Research in Finance 6, 51-72.

Auerbach, A. (2002), "Taxation and corporate financial policy," in: A.J. Auerbach und M. Feldstein (ed.), Handbook of Public Economics 3, Amsterdam: North Holland, 1251-1292.

Bradley, M., G.A. Jarrell, and E.H. Kim (1984), "On the existence of an optimal capital structure: Theory and evidence," Journal of Finance 39, 857-878.

DeAngelo, H. and R.W. Masulis (1980), "Optimal capital structure under corporate and personal taxation," Journal of Financial Economics 8, 3-29.

Desai, M.A., C.F. Foley, and J.R. Hines, Jr. (2004), "A multinational perspective on capital structure choice and internal capital markets," Journal of Finance 59, 2451-2488.

Dhaliwal, D., R. Trezevant, and S.-W. Wang (1992), "Taxes, investment related tax shields and capital structure," Journal of the American Taxation Association 14, 1-21.

Dierkens, N. (1991), "Information asymmetry and equity issues," Journal of Financial and Quantitative Analysis 26, 181-199.

D'Mello, R. and F.P. Ferris (2000), "The information effect of analyst activity at the announcement of new equity issues," Financial Management 29, 78-95.

Eckbo, E. (1996), "The valuation effects of corporate debt offerings," Journal of Financial Economics 15, 119-152.

Fischer, E.O., R. Heinkel, and J. Zechner (1989), "Dynamic capital structure choice: Theory and tests," Journal of Finance 44, 19-40.

Fuest, C., B. Huber and S.B. Nielsen (2002), "Why is the corporate tax rate lower than the personal tax rate? The role of new firms," Journal of Public Economics 87, 157-174.

Gordon, R.H. and Y. Lee (2001), "Do taxes affect corporate debt policy? Evidence from U.S. corporate tax return data," Journal of Public Economics 82, 195-224.

Graham, J.R. (1999), "Do personal taxes affect corporate financing decisions?," Journal of Public Economics 73, 147-185.

Graham, J.R. (2003), "Taxes and corporate finance: A review," Review of Financial Studies $16,1075-1129$. 
Grossman, S.J. and O.D. Hart (1982), "Corporate financial structure and managerial incentives," in: J. McCall (ed.), The economics of information and uncertainty, Chicago: University of Chicago Press, 107-140.

Huizinga, H., L. Laeven, and G. Nicodème (2008), "Capital structure and international debt shifting," Journal of Financial Economics 88, 80-118.

Jensen, M.C. (1986), "Agency costs of free cash flow, corporate finance, and take-overs," American Economic Review 76, 323-329.

King, M.A. (1977), Public policy and the corporation, London: Chapman and Hall.

King, M.A. and D. Fullerton (1984), The taxation of income from capital. A comparative study of the United States, the United Kingdom, Sweden and West Germany, Chicago und London: University of Chicago Press.

Long, M.S. and L.B. Malitz (1985), "Investment patterns and financial leverage,” in: B.M. Friedman (ed.), Corporate capital structures in the United States, Chicago: University of Chicago Press.

MacKie-Mason, J.K. (1990), "Do taxes affect corporate financing decisions?," Journal of Finance 45, 1471-1493.

Marsh, P.R. (1982), "The choice between equity and debt: An empirical study," Journal of Finance 37, 121-144.

Miller, M.H. (1977), "Debt and taxes," Journal of Finance 32, 261-275.

Mintz, J. and A.J. Weichenrieder (2005), Taxation and the financial structure of German outbound FDI, CESifo Working Paper No. 1612.

Modigliani, F. and M. Miller (1958), "The cost of capital corporation finance and the theory of investment," American Economic Review 48, 261-297.

Myers, S.C. (1984), "The capital structure puzzle,” Journal of Finance 39, 575-592.

Myers, S.C. (2001), "Capital structure," Journal of Economic Perspectives 15, 81-102.

Myers, S.C. and N.S. Majluf (1984), "Corporate financing and investment decisions when firms have information that investors do not have," Journal of Financial Economics 13, 187221.

Ramb, F. and A.J. Weichenrieder (2005), "Taxes and the financial structure of German inward FDI," Review of World Economics 141, 670-692.

Scott, D.F. (1977), "Bankruptcy, secured debt, and optimal capital structure," Journal of Finance 32, 1-19.

Shyam-Sunder, L. (1991), "The stock price effect of risky versus save debt," Journal of Financial and Quantitative Analysis 26, 549-558. 
Sinn, H.-W. (1987), Capital income taxation and resource allocation, Amsterdam: NorthHolland.

Titman, S. and R. Wessels (1988), "The determinants of capital structure choice," Journal of Finance 43, 1-19.

Zwiebel, J. (1996), "Dynamic capital structure under managerial entrenchment," American Economic Review 86, 1197-1215. 


\section{CESifo Working Paper Series}

for full list see www.cesifo-group.org/wp

(address: Poschingerstr. 5, 81679 Munich, Germany, office@cesifo.de)

2369 Hans Gersbach and Hans Haller, Exit and Power in General Equilibrium, August 2008

2370 Jan P.A.M. Jacobs and Jan-Egbert Sturm, The Information Content of KOF Indicators on Swiss Current Account Data Revisions, August 2008

2371 Oliver Hülsewig, Johannes Mayr and Timo Wollmershäuser, Forecasting Euro Area Real GDP: Optimal Pooling of Information, August 2008

2372 Tigran Poghosyan and Jakob de Haan, Determinants of Cross-Border Bank Acquisitions in Transition Economies: A Latent Class Analysis, August 2008

2373 David Anthoff and Richard S.J. Tol, On International Equity Weights and National Decision Making on Climate Change, August 2008

2374 Florian Englmaier and Arno Schmöller, Reserve Price Formation in Online Auctions, August 2008

2375 Karl Farmer, Birgit Friedl and Andreas Rainer, Effects of Unilateral Climate Policy on Terms of Trade, Capital Accumulation, and Welfare in a World Economy, August 2008

2376 Monika Bütler, Stefan Staubli and Maria Grazia Zito, The Role of the Annuity’s Value on the Decision (Not) to Annuitize: Evidence from a Large Policy Change, August 2008

2377 Inmaculada Martínez-Zarzoso, The Impact of Urbanization on $\mathrm{CO}_{2}$ Emissions: Evidence from Developing Countries, August 2008

2378 Brian Roberson and Dmitriy Kvasov, The Non-Constant-Sum Colonel Blotto Game, August 2008

2379 Ian Dew-Becker, How Much Sunlight Does it Take to Disinfect a Boardroom? A Short History of Executive Compensation Regulation, August 2008

2380 Cécile Aubert, Oliver Falck and Stephan Heblich, Subsidizing National Champions: An Evolutionary Perspective, August 2008

2381 Sebastian Buhai, Miguel Portela, Coen Teulings and Aico van Vuuren, Returns to Tenure or Seniority?, August 2008

2382 Erkki Koskela and Jan König, Flexible Outsourcing, Profit Sharing and Equilibrium Unemployment, August 2008

2383 Torberg Falch and Justina AV Fischer, Does a Generous Welfare State Crowd out Student Achievement? Panel Data Evidence from International Student Tests, September 2008 
2384 Pedro Gomes and François Pouget, Corporate Tax Competition and the Decline of Public Investment, September 2008

2385 Marko Koethenbuerger, How Do Local Governments Decide on Public Policy in Fiscal Federalism? Tax vs. Expenditure Optimization, September 2008

2386 Ronald McKinnon and Gunther Schnabl, China's Exchange Rate Impasse and the Weak U.S. Dollar, September 2008

2387 Yan-Leung Cheung, Yin-Wong Cheung and Alan T.K. Wan, A High-Low Model of Daily Stock Price Ranges, September 2008

2388 Louis Eeckhoudt and Harris Schlesinger, Changes in Risk and the Demand for Saving, September 2008

2389 Carsten Hefeker and Blandine Zimmer, Uncertainty and Fiscal Policy in an Asymmetric Monetary Union, September 2008

2390 Jay Pil Choi and Byung-Cheol Kim, Net Neutrality and Investment Incentives, September 2008

2391 Marcel Gérard, Financing Bologna, the Internationally Mobile Students in European Higher Education, September 2008

2392 Annette Alstadsæter and Knut Reidar Wangen, Corporations' Choice of Tax Regime when Transition Costs are Small and Income Shifting Potential is Large, September 2008

2393 António Afonso and Christophe Rault, 3-Step Analysis of Public Finances Sustainability: the Case of the European Union, September 2008

2394 Betsey Stevenson and Justin Wolfers, Economic Growth and Subjective Well-Being: Reassessing the Easterlin Paradox, September 2008

2395 Bernhard Eckwert and Itzhak Zilcha, Private Investment in Higher Education: Comparing Alternative Funding Schemes, September 2008

2396 Øystein Foros, Hans Jarle Kind and Jan Yngve Sand, Slotting Allowances and Manufacturers' Retail Sales Effort, September 2008

2397 Mohammad Reza Farzanegan, Illegal Trade in the Iranian Economy: Evidence from a Structural Model, September 2008

2398 Olivier Bos, Charity Auctions for the Happy Few, September 2008

2399 Robert S. Chirinko and Debdulal Mallick, The Marginal Product of Capital: A Persistent International Puzzle, September 2008

2400 Ben D'Exelle and Arno Riedl, Elite Capture, Political Voice and Exclusion from Aid: An Experimental Study, September 2008 
2401 Torben M. Andersen and Joydeep Bhattacharya, On Myopia as Rationale for Social Security, September 2008

2402 Fabienne Llense, French CEO Compensations: What is the Cost of a Mandatory Upper Limit?, September 2008

2403 Valentina Bosetti, Carlo Carraro, Alessandra Sgobbi and Massimo Tavoni, Delayed Action and Uncertain Targets. How Much Will Climate Policy Cost?, September 2008

2404 Robert G. Chambers, Rolf Färe, Shawna Grosskopf and Michael Vardanyan, Generalized Quadratic Revenue Functions, September 2008

2405 Leonidas Enrique de la Rosa, Overconfidence in a Career-Concerns Setting, September 2008

2406 Marcus Drometer and Johannes Rincke, The Design of Political Institutions: Electoral Competition and the Choice of Ballot Access Restrictions in the United States, September 2008

2407 Markku Lanne and Helmut Lütkepohl, Stock Prices and Economic Fluctuations: A Markov Switching Structural Vector Autoregressive Analysis, September 2008

2408 Thomas L. Brewer, International Energy Technology Transfers for Climate Change Mitigations, September 2008

2409 Alexander Kemnitz, Native Welfare Losses from High Skilled Immigration, September 2008

2410 Xavier Vives, Strategic Supply Function Competition with Private Information, September 2008

2411 Fabio Padovano and Roberto Ricciuti, The Political Competition-Economic Performance Puzzle: Evidence from the OECD Countries and the Italian Regions, September 2008

2412 Joan Costa-Font and Mireia Jofre-Bonet, Body Image and Food Disorders: Evidence from a Sample of European Women, September 2008

2413 Thorsten Upmann, Labour Unions - To Unite or to Separate?, October 2008

2414 Sascha O. Becker and Ludger Woessmann, Luther and the Girls: Religious Denomination and the Female Education Gap in $19^{\text {th }}$ Century Prussia, October 2008

2415 Florian Englmaier and Stephen Leider, Contractual and Organizational Structure with Reciprocal Agents, October 2008

2416 Vittorio Daniele and Ugo Marani, Organized Crime and Foreign Direct Investment: The Italian Case, October 2008 
2417 Valentina Bosetti, Carlo Carraro, Alessandra Sgobbi and Massimo Tavoni, Modelling Economic Impacts of Alternative International Climate Policy Architectures. A Quantitative and Comparative Assessment of Architectures for Agreement, October 2008

2418 Paul De Grauwe, Animal Spirits and Monetary Policy, October 2008

2419 Guglielmo Maria Caporale, Christophe Rault, Robert Sova and Anamaria Sova, On the Bilateral Trade Effects of Free Trade Agreements between the EU-15 and the CEEC-4 Countries, October 2008

2420 Yin-Wong Cheung and Daniel Friedman, Speculative Attacks: A Laboratory Study in Continuous Time, October 2008

2421 Kamila Fialová and Ondřej Schneider, Labour Market Institutions and their Effect on Labour Market Performance in the New EU Member Countries, October 2008

2422 Alexander Ludwig and Michael Reiter, Sharing Demographic Risk - Who is Afraid of the Baby Bust?, October 2008

2423 Doina Maria Radulescu and Michael Stimmelmayr, The Welfare Loss from Differential Taxation of Sectors in Germany, October 2008

2424 Nikolaus Wolf, Was Germany ever United? Evidence from Intra- and International Trade 1885 - 1933, October 2008

2425 Bruno S. Frey, David A. Savage and Benno Torgler, Noblesse Oblige? Determinants of Survival in a Life and Death Situation, October 2008

2426 Giovanni Facchini, Peri Silva and Gerald Willmann, The Customs Union Issue: Why do we Observe so few of them?, October 2008

2427 Wido Geis, Silke Uebelmesser and Martin Werding, Why go to France or Germany, if you could as well go to the UK or the US? Selective Features of Immigration to four major OECD Countries, October 2008

2428 Geeta Kingdon and Francis Teal, Teacher Unions, Teacher Pay and Student Performance in India: A Pupil Fixed Effects Approach, October 2008

2429 Andreas Haufler and Marco Runkel, Firms' Financial Choices and Thin Capitalization Rules under Corporate Tax Competition, October 2008

2430 Matz Dahlberg, Heléne Lundqvist and Eva Mörk, Intergovernmental Grants and Bureaucratic Power, October 2008

2431 Alfons J. Weichenrieder and Tina Klautke, Taxes and the Efficiency Costs of Capital Distortions, October 2008 